\title{
An Increase in TNF-a Levels in Fetus due to Prenatal Ischemic Hypoxia
}

\author{
Ratna Indriawati $^{1 *}$, Nurvita Risdiana ${ }^{1}$, Tunjung Wibowo ${ }^{2}$ \\ ${ }^{1}$ Department of Physiology, Faculty of Medicine and Health Sciences, Universitas Muhammadiyah Yogyakarta, Yogyakarta, \\ Indonesia; ${ }^{2}$ Departement of Child Health, Faculty of Medicine, Public Health and Nursing, Universitas Gadjah Mada, Dr. Sardjito \\ General Hospital, Yogyakarta, Indonesia
}

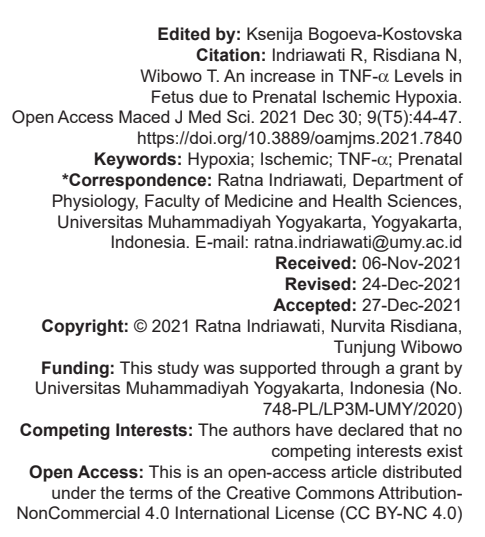

Abstract

BACKGROUND: Prenatal ischemic hypoxia can increase mortality and morbidity and affect the immune system. One of the immune responses is tumor necrosis factor- $\alpha$ (TNF- $\alpha$ ) levels. However, the cellular mechanism of immune response abnormalities due to prenatal hypoxia remains unclear. An 11-17-day-old fetus is a sensitive period of neural development. Brain ischemia will cause cell dysfunction and can even affect TNF- $\alpha$ levels. Thus, how prenatal ischemic hypoxia increases TNF- $\alpha$ levels in the fetus remains unclear.

AIM: This study aims to examine the effect of the onset and duration of prenatal ischemic hypoxia on TNF- $\alpha$ levels.

METHODOLOGY: An experimental study with a post-test control design was conducted. Thirty Rattus norvegicus were induced with prenatal ischemic hypoxia (embryos aged 7, 12, and 17 days). The independent variable was prenatal ischemic hypoxia, while the dependent variable was TNF- $\alpha$ levels. TNF- $\alpha$ was measured using the ELISA technique and was carried out when the fetus was 19 days old (E19). The TNF- $\alpha$ was analyzed using ANOVA, and the limit of significance was set at $p<0.05$

RESULTS: The TNF- $\alpha$ levels in the prenatal ischemic hypoxia group were statistically higher than in the control group $(p<0.05)$. The more the onset and the longer the ischemic hypoxia is, the higher the TNF-level $(p<0.05)$.

CONCLUSION: The prenatal ischemic hypoxia increased TNF- $\alpha$ levels in the fetus.

\section{Introduction}

The incidence of ischemic hypoxia is approximately $2-4 / 1000$ births, where $60 \%$ of babies are born prematurely. The incidence of asphyxia neonatorum in Indonesia is approximately 40/1000 live births. In total, 110,000 neonates die every year due to asphyxia. Perinatal morbidity reflects the presence of dangerous antenatal conditions [1], [2], [3].

Hypoxia is associated with immunity [4], [5], [6], cognitive [7], [8], motor, and behavioral aspects [4], [9], [10]. One form of immune response is the level of tumor necrosis factor- $\alpha($ TNF- $\alpha)$ [11], [12]. However, the cellular mechanism of prenatal immune response abnormalities due to hypoxia remains unclear. The exact mechanism of the immune response, especially in relation to prenatal ischemic hypoxia, is still debatable. One form of immune response is a change in TNF- $\alpha$ levels. Furthermore, the effect of prenatal hypoxia on TNF- $\alpha$ is still unclear. Cerebral hypoxia can affect the cytokines TGF- $\beta$ and TNF- $\alpha$ and any brain injury can lead to an increase in TNF- $\alpha$. All of these cytokines can be found in the cerebrospinal liquor and serum. The cytokines IL-1 $\beta$ and TNF- $\alpha$ can biologically increase tissue catabolism; thus, pathological brain changes due to the direct effect of cerebral hypoxia will be more severe. TNF- $\alpha$ is released by microglial cells, which are stressed cells due to cerebral hypoxic stressors [12], [13], [14].

How the onset and duration of prenatal ischemic hypoxia affect TNF- $\alpha$ levels remain unclear. This study aims to examine the effect of onset and duration of prenatal ischemic hypoxia on TNF- $\alpha$ levels.

\section{Methods}

This research was an experimental study with a post-test with a control group design. This study has two variables, namely, the dependent variable and the independent variable. The independent variable was prenatal ischemic hypoxia, while the dependent variable was the TNF- $\alpha$ level in the blood to know the effect of the onset and duration of prenatal ischemic hypoxia on TNF- $\alpha$ levels. 
The subject in this study was animal, animal supply was carried out by selecting healthy Rattus norvegicus parent Sprague-Dawley strains which were pregnant at 7,12 , and 17 days. The subjects were 24 fetuses with bodyweight $<5.50 \mathrm{~g}$ in the gestational phase of Rattus novergicus Sprague-Dawley rats based on Delcour et al. (2012). They were divided into three groups named hypoxia ischemic $(\mathrm{HI}) 7, \mathrm{HI} 12$, and $\mathrm{HI} 17$ for experimental groups and one control group (C) with 17 days of gestation which consists of six subjects in each group. The subjects were kept the food and drink ad libitum. The experiment groups were ischemic hypoxia induction by unilateral uterine artery ligation in $7^{\text {th }}, 12^{\text {th }}$, and $17^{\text {th }}$ day of fetal age in day of gestation under anesthesia using chloral hydrate $350 \mathrm{mg} / \mathrm{kg}$ intramuscular. The other group was the control group which was not induced by prenatal ischemic hypoxia.

The immune response in this study was examined by measuring TNF- $\alpha$ levels in the blood using the enzyme immuno assay (ELISA) technique. The TNF- $\alpha$ measurement was carried out when the fetus was 19 days old (E19). TNF- $\alpha$ levels were analyzed using ANOVA to know the differences between groups.

\section{Results}

Table 1 shows the data on the body weight of rats. The Kruskal-Wallis test of these data denoted a significant effect. Post hoc Mann-Whitney test showed that the birth weight of children in the HI7, HI12, and $\mathrm{HI} 17$ groups was lower than that of the control group, respectively, $(p=0.002)$. However, the bodyweight of the study subjects met the inclusion criteria (weight in the treatment group $<5.5 \mathrm{~g}$ ).

Table 1: The body weights of rats

\begin{tabular}{|c|c|c|c|}
\hline Groups & $\mathrm{N}$ & Means \pm SD (g) & $\mathrm{p}$ \\
\hline $\mathrm{HI}_{7}$ & 6 & $4.48 \pm 0.31$ & $0.001^{*}$ \\
\hline $\mathrm{HI}_{12}^{\prime}$ & 6 & $4.92 \pm 0.83$ & \\
\hline $\mathrm{HI}_{17}^{2}$ & 6 & $4.84 \pm 0.36$ & \\
\hline C & 6 & $6.46 \pm 0.29$ & \\
\hline
\end{tabular}

The mean weight of the placenta of 19-dayold fetuses in the prenatal ischemic hypoxia group was lighter than that of the control group (Table 1). Furthermore, normality and homogeneity tests were carried out. The results of the normality test of Shapiro-Wilk's data showed $p=0.02$. Placental weight data were analyzed by Kruskal-Wallis test. The results of the Kruskal-Wallis test showed a statistically significant decrease in placental weight in the control group compared to the brain weight in the control group $(p=0.002)$ (Tables 2 and 3).

Fetal plasma was taken to check the TNF- $\alpha$ levels using the ELISA method. The data obtained were further analyzed using the ANOVA test. ANOVA test
Table 2: The weight of the placenta of 19-day-old fetus

\begin{tabular}{llll}
\hline Groups & \multicolumn{2}{l}{ Placenta weight $(\mathrm{mg})$} & \\
\cline { 2 - 4 } & Minimum & Maximum & Means $\pm \mathrm{SD}$ \\
\hline $\mathrm{HI}_{7}$ & 560 & 640 & $593 \pm 80$ \\
$\mathrm{HI}_{12}$ & 440 & 510 & $480 \pm 70$ \\
$\mathrm{HI}_{17}$ & 580 & 640 & $582 \pm 60$ \\
$\mathrm{C}$ & 730 & 810 & $746 \pm 80$ \\
& & $\mathrm{p}=0.0001^{*}$ \\
\hline${ }^{*}$ One way ANOVA test, significance $P<0.05 . \mathrm{HI}_{7}, \mathrm{HI}_{12}, \mathrm{HI}_{17}$ : rat groups with prenatal ischemic hypoxia on the \\
$7^{\mathrm{h}}, 2^{\mathrm{th}}$, and $17^{\mathrm{h}}$ days of gestational age and control group.
\end{tabular}

results showed a significant difference $(p<0.05)$. Fetal plasma TNF- $\alpha$ levels were elevated in the prenatal ischemic hypoxia group. In other words, the longer the prenatal ischemic hypoxia is, the greater the TNF level.

Table 3: The TNF-1 $\alpha$ level in the fetus at $19^{\text {th }}$ day

\begin{tabular}{llll}
\hline Groups & \multicolumn{2}{l}{ TNF-1 $\alpha$ Level $(\mathrm{pg} / \mathrm{ml})$} & \\
\cline { 2 - 4 } & Minimum & Maximum & Means \pm SD \\
\hline HI7 & 87.05 & 160.94 & 108.92 \\
HI12 & 77.39 & 113.36 & 100.69 \\
HI17 & 85.49 & 107.39 & 95.91 \\
C & 78.61 & 92.61 & 88.79 \\
& & & $p=0.001^{*}$ \\
\hline
\end{tabular}

*One way ANOVA test, significance $P<0.05 . \mathrm{HI}_{7} \mathrm{HI}_{12} \mathrm{HI}_{14}$ : rat groups with prenatal ischemic hypoxia on the $7^{\text {th }}, 12^{\text {th }}$, and $17^{\text {th }}$ day of gestational age and control group.

\section{Discussion}

This study showed that the weight of the hypoxic rat placenta was lower than that of the control group. Prenatal hypoxia exposure in rats causes restriction of growth and development of several body systems [3], [15], [16]. The placenta affects the growth of the fetus. Prenatal hypoxia can affect placental function, leading to placental dysfunction that plays a role in fetal growth restriction. Placental-mediated fetal growth restriction occurs through chronic fetal hypoxia due to poor placental perfusion through various mechanisms. Maternal vascular malperfusion is the most common placental disease that contributes to fetal growth restriction [17], [18].

Several studies have shown that hypoxia affects immunity [5], [6] specifically the TNF- $\alpha$ levels. This study indicated that TNF- $\alpha$ levels were higher as the duration of prenatal ischemic hypoxia increases. Furthermore, the results showed that the longer the prenatal hypoxia is, the higher the TNF value will be. It aligns with the previous research [19], [20], [21], revealing that hypoxia causes an increase in TNF [22], [23].

TNF- $\alpha$ is produced from various cells such as lymphoid cells, cardiac myocytes, activated macrophages, endothelial cells, mast cells, fibroblasts, neurons, and adipose tissue. It is mainly secreted as a type II 212-amino acid long transmembrane protein arranged in a stable homotrimer. The secreted form of human TNF- $\alpha$ develops a triangular pyramidal shape and weights about $17-\mathrm{kDa}$. TNF- $\alpha$ is expressed in largely segregated populations of $C D 11 b^{+} C D 45 \mathrm{dim}$ microglia and $\mathrm{CD}_{11} \mathrm{~b}^{+} \mathrm{CD} 45$ high macrophages in mice [22], [24]. 
Actually, TNF is a weak inducer of apoptosis (TWEAK). TNF- $\alpha$ was initially described as an inducer of apoptosis in altered cell lines. TWEAK acts by binding to the TNF- $\alpha$ receptor (TNFR) with fibroblast growth factor-inducible 14 (Fn14), the smallest member of the TNF receptor superfamily (TNFR). The specificity of TWEAK binding to Fn14 has been confirmed in several experiments [11], [25]. TWEAK is expressed by monocytes, dendritic cells, and natural killer (NK) cells. Macrophages/monocytes are the main soluble TWEAK (sTWEAK) in inflammatory tissues. Moreover, immune organs, including the spleen, lymph nodes, and appendix, also express TWEAK [21], [26]. TWEAK and Fn14 expression in normal tissue were relatively low. Increased TWEAK and Fn14 are usually seen in response to stress, tissue injury, or remodeling. TWEAK-mediated activation of Fn14 optimally promotes a productive tissue response after injury. However, excessive or persistent upregulation of Fn14 and TWEAK/Fn14 activation frequently leads to various pathological responses. The TWEAK/Fn14 signaling pathway participates in a variety of biological activities, including proliferation, differentiation, migration and cell death (apoptosis/necrosis), angiogenesis, and immune responses [11], [25], [27].

Besides, tissue injury and infection can stimulate TNF- $\alpha$ production in the periphery. TNF- $\alpha$ is a large molecule and circulating cytokine naturally cannot cross the blood-brain barrier (BBB) under normal physiological situations [19], [28]. However, it reaches the brain using several immune-mediated pathways and transfers signals from the periphery to the CNS. The rapid transmission pathway is where primary afferent nerves innervate the site of inflammation. Another slow transmission pathway consists of cytokines that start from the circumventricular organs and choroid plexus and diffuse into the brain parenchyma by mass transmission. In the third pathway [29], [30], TNF- $\alpha$ is transported across the BBB under a particular saturated transport system. TNF- $\alpha$ is a potent inducer of the inflammatory response, a key regulator of innate immunity and plays a vital role in regulating Th1 immune responses against intracellular bacterial and certain viral infections [31]. However, impaired TNF- $\alpha$ can also contribute to many pathological situations and immunocompromised diseases. It indicated that prenatal ischemic hypoxia causes elevated TNF- $\alpha$ levels [20], [32]. Nonetheless, further research is needed on immune disorders in humans with prenatal hypoxia.

\section{Conclusion}

The prenatal ischemic hypoxia increased TNF- $\alpha$ levels in the fetus. Further research is needed on immune disorders in humans with prenatal hypoxia.

\section{Acknowledgment}

The present study was funded by Universitas Muhammadiyah Yogyakarta, Indonesia (grant number:748-PL/LP3M-UMY/2020). The authors would like to thank Satria (Laboratory, Faculty of Medicine and Health Sciences, Universitas Muhammadiyah Yogyakarta) for their technical assistance.

\section{References}

1. Bakker MK, Bergman JE, Krikov S, Amar E, Cocchi G, Cragan J, et al. Prenatal diagnosis and prevalence of critical congenital heart defects: An international retrospective cohort study. BMJ Open. 2019;9(7):e028139. https://doi.org/10.1136/ bmjopen-2018-028139

PMid:31270117

2. Aljunaidy MM, Morton JS, Cooke CM, Davidge ST. Prenatal hypoxia and placental oxidative stress: Linkages to developmental origins of cardiovascular disease. Am J Physiol Regul Integr Comp Physiol. 2017;313(4):R395-9. https://doi. org/10.1152/ajpregu.00245.2017

PMid:28794104

3. Gilani K, Vafakhah M. Hypoxia: A review. Arch Adv Biosci. 2010;1(2):43-60.

4. Taylor CT, Colgan SP. Regulation of immunity and inflammation by hypoxia in immunological niches. Nat Rev Immunol. 2017;17(12):774-85. https://doi.org/10.1038/nri.2017.103 PMid:28972206

5. Indriawati R. The number of lymphocyte and monosit due to hypoxic hypoxia. J Health Med Nurs. 2015;17:62-4.

6. Draghiciu O, Lubbers J, Nijman HW, Daemen T. Myeloid derived suppressor cells-an overview of combat strategies to increase immunotherapy efficacy. Oncoimmunology. 2015;4(1):e954829. https://doi.org/10.4161/21624011.2014.954829 PMid:25949858

7. Indriawati R, Aswin S, Susilowati R, Partadiredja G. Prenatal hypoxia-ischemia decreases spatial memory and increases aggression during adolescence. Physiol Int. 2018;105(3):210-24. https://doi.org/10.1556/2060.105.2018.3.21 PMid:30282486

8. Indriawati R, Aswin S, Partadiredja G, Susilowati R. Spatia memory in adulthood rat with prenatal hypoxia-ischaemia. Adv Sci Lett. 2018;23(12):12665-9. https://doi.org/10.1166/ asl.2017.10842

9. Sab IM, Ferraz MM, Amaral TA, Resende AC, Ferraz MR, Matsuura C, et al. Prenatal hypoxia, habituation memory and oxidative stress. Pharmacol Biochem Behav. 2013;107:24-8. https://doi.org/10.1016/j.pbb.2013.04.004 PMid:23584097

10. Rauchová H, Vokurková M, Koudelová J. Hypoxia-induced lipid peroxidation in the brain during postnatal ontogenesis. Physiol Res. 2012;61:S89-101. https://doi.org/10.33549/ physiolres.932374

PMid:22827877

11. Mueller. HHS public access. Physiol Behav. 2016;176(1):139 48. https://doi.org/10.1002/jnr.23540

12. Paardekooper LM, Bendix MB, Ottria A, de Haer LW, Ter Beest M, Radstake TR, et al. Hypoxia potentiates monocyte-derived 
dendritic cells for release of tumor necrosis factor a via MAP3K8. Biosci Rep. 2018;38(6):BSR20182019. https://doi.org/10.1042/ BSR20182019

PMid:30463908

13. Mercogliano MF, Bruni S, Mauro F, Elizalde PV, Schillaci R. Harnessing Tumor Necrosis Factor Alpha to Achieve Effective Cancer Immunotherapy. Cancers (Basel) 2021;13:564. https:// doi.org/10.3390/cancers13030564

PMid:33540543

14. Osborne LM, Monk C. Perinatal depression-the fourth inflammatory morbidity of pregnancy?: Theory and literature review. Psychoneuroendocrinology. 2013;38(10):1929-52. https://doi.org/10.1016/j.psyneuen.2013.03.019 PMid:23608136

15. Dunwoodie SL. The role of hypoxia in development of the mammalian embryo. Dev Cell. 2009;17(6):755-73. https://doi. org/10.1016/j.devcel.2009.11.008 PMid:20059947

16. Uyun HF, Indriawati R. Effect of hypoxia duration to the erythrocyte and hemoglobin rattus norvegicus. Mutiara Med. 2013;13(1):49-54.

17. Groten T, Lehmann T, Schleußner E, PETN Study Group. Does Pentaerytrithyltetranitrate reduce fetal growth restriction in pregnancies complicated by uterine mal-perfusion? Study protocol of the PETN-study: A randomized controlled multicenter-trial. BMC Pregnancy Childbirth. 2019;19(1):336. https://doi.org/10.1186/s12884-019-2456-7

PMid:31521118

18. Guerby P, Tasta O, Swiader A, Pont F, Bujold E, Parant $O$, et al. Role of oxidative stress in the dysfunction of the placental endothelial nitric oxide synthase in preeclampsia. Redox Biol. 2021;40:101861. https://doi.org/10.1016/j.redox.2021.101861 PMid:33548859

19. Crisostomo PR, Wang $Y$, Markel TA, Wang M, Lahm T, Meldrum DR. Human mesenchymal stem cells stimulated by TNF- $\alpha$, LPS, or hypoxia produce growth factors by an NFKBbut not JNK-dependent mechanism. Am J Physiol Cell Physiol. 2008;294(3):675-82. https://doi.org/10.1152/ajpcell.00437.2007

20. Carpentier PA, Dingman AL, Palmer TD. Placental TNF- $\alpha$ signaling in illness-induced complications of pregnancy. Am J Pathol. 2011;178(6):2802-10. https://doi.org/10.1016/j. ajpath.2011.02.042

21. Vendrell J, Maymó-Masip E, Tinahones F, García-España A, Megia A, Caubet E, et al. Tumor necrosis-like weak inducer of apoptosis as a proinflammatory cytokine in human adipocyte cells: Up-regulation in severe obesity is mediated by inflammation but not hypoxia. J Clin Endocrinol Metab. 2010;95(6):2983-92. https://doi.org/10.1210/jc.2009-2481

PMid:20382683
22. Ma Y, Li Y, Jiang L, Wang L, Jiang Z, Wang Y, et al. Macrophage depletion reduced brain injury following middle cerebral artery occlusion in mice. J Neuroinflammation. 2016;13:38. https://doi. org/10.1186/s12974-016-0504-z

PMid:26873581

23. Tashiro N, Segawa R, Tobita R, Asakawa $\mathrm{S}$, Mizuno $\mathrm{N}$, Hiratsuka M, et al. Hypoxia inhibits TNF- $\alpha$-induced TSLP expression in keratinocytes. PLoS One. 2019;14(11):e0224705. https://doi.org/10.1371/journal.pone.0224705

PMid:31682627

24. Ritzel RM, Patel AR, Grenier JM, Crapser J, Verma R, Jellison ER, et al. Functional differences between microglia and monocytes after ischemic stroke. J Neuroinflammation. 2015;12:106. https://doi.org/10.1186/s12974-015-0329-1

PMid:26022493

25. Winkles JA. The TWEAK-Fn14 cytokine-receptor axis: Discovery, biology and therapeutic targeting. Nat Rev Drug Discov. 2008;7(5):411-25. https://doi.org/10.1038/nrd2488 PMid: 18404150

26. Bird TG, Lu WY, Boulter L, Gordon-Keylock S, Ridgway RA, Williams $\mathrm{MJ}$, et al. Bone marrow injection stimulates hepatic ductular reactions in the absence of injury via macrophagemediated TWEAK signaling. Proc Natl Acad Sci USA. 2013;110(16):6542-7. https://doi.org/10.1073/pnas.1302168110 PMid:23576749

27. Mastaglia FL. Pathological changes in skeletal muscle in acromegaly. Acta Neuropathol. 1973;24(4):273-86. https://doi. org/10.1007/BF00685584

PMid:4722362

28. Munford RS, Pugin J. Normal responses to injury prevent systemic inflammation and can be immunosuppressive. Am J Respir Crit Care Med. 2001;163(2):316-21. https://doi. org/10.1164/ajrccm.163.2.2007102 PMid:11179099

29. WalkerAK, Kavelaars A, Heijnen CJ, Dantzer R. Neuroinflammation and comorbidity of pain and depression. Pharmacol Rev. 2014;66(1):80-101. https://doi.org/10.1124/pr.113.008144 PMid:24335193

30. Zweier NIH public access. Bone. 2014;23(1):1-7. https://doi org/10.1016/j.jpsychires.2011.08.006

31. Murphy TJ, Paterson HM, Mannick JA, Lederer JA. Injury, sepsis and the regulation of Toll-like receptor responses. J Leukoc Biol. 2004;75(3):400-7. https://doi.org/10.1189/jlb.0503233 PMid: 14557385

32. Amor S, Puentes F, Baker D, van der Valk P. Inflammation in neurodegenerative diseases. Immunology. 2010;129(2):154-69. https://doi.org/10.1111/j.1365-2567.2009.03225.x

PMid:20561356 